\title{
Antitumor effects of candidone extracted from Derris indica (Lamk) Bennet in cholangiocarcinoma cells
}

\author{
Benjawan Kurasug ${ }^{1,2}$, Veerapol Kukongviriyapan ${ }^{1,2}$, Auemduan Prawan ${ }^{1,2}$, \\ Chavi Yenjai ${ }^{3}$, Sarinya Kongpetch ${ }^{1,2 *}$ \\ ${ }^{1}$ Department of Pharmacology, Faculty of Medicine, Khon Kaen University, ${ }^{2}$ Cholangiocarcinoma Research Institute, Khon \\ Kaen University, ${ }^{3}$ Natural Products Research Unit, Department of Chemistry and Centre of Excellence for Innovation in \\ Chemistry, Faculty of Science, Khon Kaen University, Khon Kaen 40002, Thailand
}

*For correspondence: Email: sarinyako@kku.ac.th; Tel: +66-43348-397

\begin{abstract}
Purpose: To investigate the antitumor effect of candidone extracted from Derris indica, against human cholangiocarcinoma (CCA) cells.

Methods: Candidone was purified from the hexane extract of Derris indica fruit. CCA cell lines, KKUM156 and KKU-M213, were treated with candidone. Sulforhodamine B (SRB) assay and acridine orange/ethidium bromide (AO/EB) staining were used to investigate the effects of candidone on cell proliferation and induction of apoptosis, respectively. The effect on cell migration was assessed by wound healing assay. Reverse transcription-quantitative polymerase chain reaction (RT-qPCR) was employed to assess the effects of candidone on the expression of genes that regulate proliferation and apoptosis.

Results: Candidone exerted strong anticancer effects on CCA cells. The agent suppressed CCA cell proliferation and induced apoptotic cell death. RT-qPCR assay revealed that candidone significantly increased the expression of anti-proliferative and pro-apoptotic genes, including p21 and Bax, and decreased the expression of anti-apoptotic genes, including Bcl-2 and survivin. Moreover, candidone inhibited the migration of CCA cells induced by IGF-1.

Conclusion: Candidone exhibits potent antitumor effect on CCA cells. These findings suggest that candidone is potentially suitable for the management of CCA and, therefore, warrants further investigation.
\end{abstract}

Keywords: Candidone, Derris indica, Cholangiocarcinoma, Cytotoxicity, Apoptosis

This is an Open Access article that uses a funding model which does not charge readers or their institutions for access and distributed under the terms of the Creative Commons Attribution License (http://creativecommons.org/licenses/by/4.0) and the Budapest Open Access Initiative (http://www.budapestopenaccessinitiative.org/read), which permit unrestricted use, distribution, and reproduction in any medium, provided the original work is properly credited.

Tropical Journal of Pharmaceutical Research is indexed by Science Citation Index (SciSearch), Scopus, International Pharmaceutical Abstract, Chemical Abstracts, Embase, Index Copernicus, EBSCO, African Index Medicus, JournalSeek, Journal Citation Reports/Science Edition, Directory of Open Access Journals (DOAJ), African Journal Online, Bioline International, Open-J-Gate and Pharmacy Abstracts

\section{INTRODUCTION}

The incidence of cholangiocarcinoma (CCA) is increasing worldwide [1]. The highest incidence is in Southeast Asia, especially Thailand, Laos, and Cambodia [2]. Cholangiocarcinogenesis results from multiple factors, particularly parasitic infestation by Opisthorchis viverrini. The most effective treatment of CCA for non-metastatic stage is the complete surgical removal of the tumor. However, in metastatic or locally advanced CCA, chemotherapy and radiotherapy 
are provided as palliative treatment, and show poor responsiveness [3]. To improve treatment outcome, many attempts have focused on the combination of chemotherapy [4] and molecularly targeted therapy [5]. However, drug resistance is a problem that frequently results in treatment failure [1]. For this reason, therapeutic strategies need to be improved in order to overcome this fatal malignancy.

Natural compounds from medicinal plants have gained much attention during the past decades. Phytochemicals with bio-active properties, including antioxidant and antitumor effects, have been widely studied. These may shed some light on potential candidates in preclinical study of anticancer agents [6]. Importantly, many phytochemicals have been shown to suppress cellular signaling pathways and promote cancer cell death. They behave like pro-oxidants, increasing oxidative stress in cancer cells by inhibiting ROS scavenging system, inactivating pro-survival signaling pathways, and finally triggering apoptotic cell death [7]. Bioflavonoids are a large group of bioactive compounds that mediate antitumor effects in many cancer models. For example, apigenin exhibits antiproliferation and induces apoptosis in renal carcinoma [8]. In CCA, luteolin suppresses the proliferation and migration of CCA cell lines [9].

Derris indica is a medicinal plant that is widely grown in Southeast Asia, including the southern part of Thailand. The extracted compounds from Derris indica exhibit various pharmacological properties such as antioxidant, antimicrobial, anti-inflammatory, and anti-diabetic activities [10]. Its cytotoxic effect on cancer cells has been demonstrated in HepG2 and CCA cell lines. Candidone is a flavanone derivative extracted from the fruit of Derris indica. Among 16 compounds that are extracted from Derris indica, candidone is one of the most potent cytotoxic compounds against CCA cells [11]. Thus, candidone represents a potential therapeutic compound that warrants further study. The present study aims to investigate antitumor effects of candidone on cell proliferation, apoptosis and migration in CCA cells.

\section{EXPERIMENTAL}

\section{Materials}

Ham F12 media, fetal bovine serum (FBS) and other cell culture reagents were purchased from Gibco BRL Life Technologies (Grand Island, NY, USA). Sulforhodamine B (SRB) was obtained from Sigma-Aldrich (St Louis, MO, USA). Candidone was provided by Assoc Prof Chavi
Yenjai, Natural Products Research Unit, Department of Chemistry and Centre for Innovation in Chemistry, Faculty of Science, Khon Kaen University. Candidone was purified from the hexane extract of Derris indica fruit, as described previously [11].

\section{Cell lines and cell culture conditions}

The human cholangiocarcinoma cell lines including KKU-M156 and KKU-M213, were kindly provided by Prof. Banchob Sripa of the Department of Pathology, Faculty of Medicine, Khon Kaen University. These CCA cells were cultured in Ham F12 medium supplemented with $10 \%$ fetal bovine serum, $100 \mathrm{U} / \mathrm{mL}$ penicillin $\mathrm{G}$ and $100 \mu \mathrm{g} / \mathrm{mL}$ streptomycin and maintained in 5 $\% \mathrm{CO}_{2}$ incubator at $37{ }^{\circ} \mathrm{C}$. The cells were trypsinized with $0.25 \%$ trypsin-EDTA and media was renewed every 2 to 3 days.

\section{Cell viability assay}

Briefly, KKU-M156 and KKU-M213 cell lines were plated in a 96-well plate at density of 7,500 cells/well. After exposure to candidone at various concentrations for 8 or $24 \mathrm{~h}$, SRB assay was performed as previously described [12]. Briefly, the cells were fixed with trichloroacetic acid and stained with protein-bound SRB dye. The dye was dissolved with Tris base solution and measured the absorbance at $540 \mathrm{~nm}$ using microplate reader.

\section{Fluorescence-acridine orange/ethidium bromide (AO/EB) staining}

AO/EB fluorescence staining was employed to measure live and apoptotic cells as previously described [13]. After treatment with $0,2.5$, or 5 $\mu \mathrm{g} / \mathrm{mL}$ of candidone, cultured cells were stained with $A O$ and $E B$ (each $1 \mu \mathrm{g} / \mathrm{mL}$ ). The images were taken under a Nikon Eclipse TS100 inverted microscope. The percentage of live and apoptotic cells were calculated and divided by total number of cells in the same area.

\section{Quantitative real-time polymerase chain reaction}

KKU-M156 cells were seeded in a 6 well-plate at a density of 300,000 cells/well. After exposure to candidone at various concentrations for 6 or 24 h, total RNA was extracted using TriZol ${ }^{\circledR}$ reagent (Sigma-Aldrich, St. Louis, MO, USA), according to the manufacturer's instructions. Total RNA (1 $\mu \mathrm{g}$ ) was converted to $\mathrm{CDNA}$ using iScript ${ }^{\mathrm{TM}} \mathrm{CDNA}$ Synthesis Kit (Bio-Rad, Hercules, CA, USA) following the manufacturer's protocol. The Fifty nanograms of cDNA served as template for real- 
time PCR. CDKN1A, Bax, BCL-2, BIRC5, and $\beta$ actin mRNA expression level were analyzed with Taqman gene expression assay using TaqMan ${ }^{\mathrm{TM}}$ Fast Advanced Master Mix and Taqman probes (CDKN1A, Hs00355782_m1; Bax, Hs00180269_m1; BCL-2, Hs00608023_m1; BIRC5, Hs04194392_s1; and $\beta$-actin, Hs99999903 m1) on a QuantStudio ${ }^{\top M} 6$ Flex Real-Time Refurbished PCR System (Applied Biosystems ${ }^{\mathrm{TM}}, \mathrm{CA}, \mathrm{USA}$ ). To determine the relative expression of genes, the fold changes were analyzed with a cycle threshold $(\mathrm{Ct})$ in the linear range of amplification. Relative mRNA expression of the interested genes was expressed as a ratio to $\beta$-actin mRNA.

\section{Wound healing assay}

The scratch wound healing assay was employed to evaluate cell migration as previously described [9]. Briefly, KKU-M156 cells were seeded into a 24-well plate at a density of 250,000 cells/well and allowed to grow for $24 \mathrm{~h}$. An opened wound was scratched using a sterile $200 \mu \mathrm{L}$ pipette tip. After removing detached cells, cells were treated with $50 \mathrm{nM}$ of insulin like growth factor-1 (IGF-1) alone or with various concentrations of candidone. The images of the opened wound were captured from 0 to $48 \mathrm{~h}$. The closing of wound area was represented the capability of cell migration. The distance of closing wound was determined using Image-Pro Plus software (Media Cybernetics, LP, USA).

\section{Statistical analysis}

Statistical differences between the control and treatment groups were analyzed using Student's t-test and one-way analysis of variance (ANOVA) using SPSS software. The results were considered to be statistically significant if $p<$ 0.05 .

\section{RESULTS}

\section{Candidone suppresses cell proliferation in CCA cells}

To determine the efficacy of candidone (Figure 1) in CCA cells, two CCA cell lines; KKU-M156 and KKU-M213 were exposed to various concentrations from $0.5-10 \mu \mathrm{g} / \mathrm{mL}$ for 8 and 24 h. After a 6-hour exposure, phase-contrast microscopy revealed an increase in dead cells as the concentration of candidone increased from 2.5 to $10 \mu \mathrm{g} / \mathrm{mL}$ (data not shown). The effect of candidone on cell viability was measured by SRB assay. As shown in Figure 2, candidone exhibits antiproliferative effect in a concentration- and time-dependent manner in KKU-M156 (Figure 2
A) and KKU-M213 (Figure $2 \mathrm{~B}$ ). $\mathrm{IC}_{50}$ values at 8 and 24-h for KKU-M156 cells were 6.00 and 4.24 $\mu \mathrm{g} / \mathrm{mL}$, respectively, and $\mathrm{IC}_{50}$ values for KKUM213 cells were 5.70 and $5.74 \mu \mathrm{g} / \mathrm{mL}$, respectively cells (Figure $2 \mathrm{C}$ ). The results suggest that candidone in the micromolar range mediates anticancer effects in both CCA cells.<smiles>COc1cc(OC)c2c(c1CC=C(C)C)O[C@H](c1ccccc1)CC2=O</smiles>

Figure 1: Chemical structure of candidone

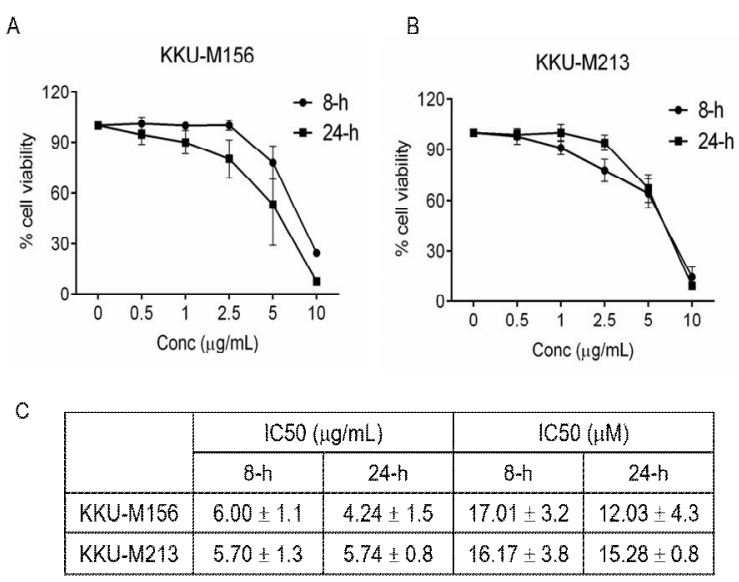

Figure 2: Candidone induces antiproliferation in a concentration-dependent manner in CCA cells. KKUM156 (A) and KKU-M213 (B) cells were treated with various concentrations of candidone $(0-10 \mu \mathrm{g} / \mathrm{mL})$ for 8 and $24 \mathrm{~h}$. After treatment, the cell viability was determined by SRB assay. The $\mathrm{IC}_{50}$ values for $\mathrm{KKU}$ M156 and KKU-M213 cells are shown as mean \pm SD (C) from three independent experiments

\section{Candidone induces apoptosis in CCA cells}

Since candidone mediated antiproliferation in CCA cells, we then determined whether candidone can induce apoptosis in CCA cells. KKU-M156 cells were treated with $0,2.5$, and 5 $\mu \mathrm{g} / \mathrm{mL}$ of concentration for $24 \mathrm{~h}$, and cell death was assessed by fluorescence staining (AO/EB). As illustrated in Figure 3, candidone significantly suppressed cell growth (Figure 3A) compared with the untreated control. After $24 \mathrm{~h}$, apoptotic cells increased by 23 and $42 \%$ when treated with 2.5 and $5 \mu \mathrm{g} / \mathrm{mL}$ of candidone, respectively, compared to untreated control (Figure $3 \mathrm{~B}$ ). 

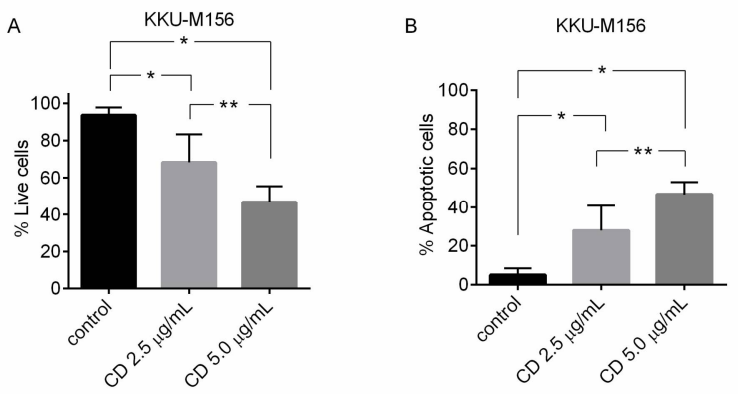

Figure 3: Candidone induced apoptosis in CCA cells. After treatment with candidone (CD) $(0,2.5$ and 5 $\mu \mathrm{g} / \mathrm{mL}$ ) for $24 \mathrm{~h}$, KKU-M156 cells were stained with fluorescent dye $A O / E B$. The numbers of live $(A)$ and apoptotic cells $(B)$ were counted, and the percent of the total number of cells was calculated. Results are expressed as mean \pm SD from three independent experiments; ${ }^{*} p<0.05$ versus control group; ${ }^{*} p<$ 0.05 versus each treatment group

\section{Candidone modulates expressions of genes involved in proliferation and apoptosis}

To examine the mechanism by which candidone suppressed cell proliferation and induction of cell death, the expression of genes involved in regulation of cell proliferation (CDKN1A or p21) and apoptosis (Bax, BCl-2, BIRC5) were measured using RT-qPCR. Candidone upregulated $p 21$ expression in a concentration- and time-dependent manner. The increase of p21 level was detected as early as $6 \mathrm{~h}$ and the levels were markedly increased at $24 \mathrm{~h}$ (Figure $4 \mathrm{~A}$ ).
A

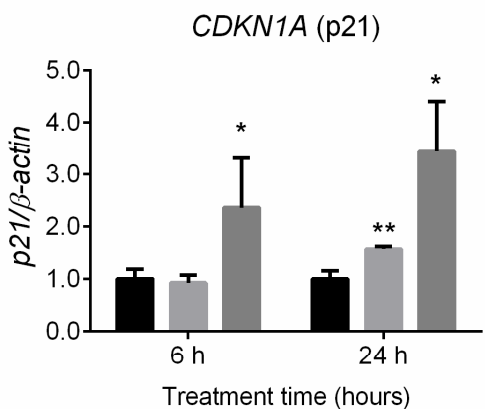

C

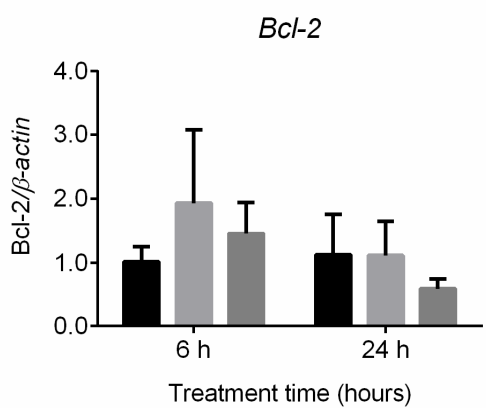

B

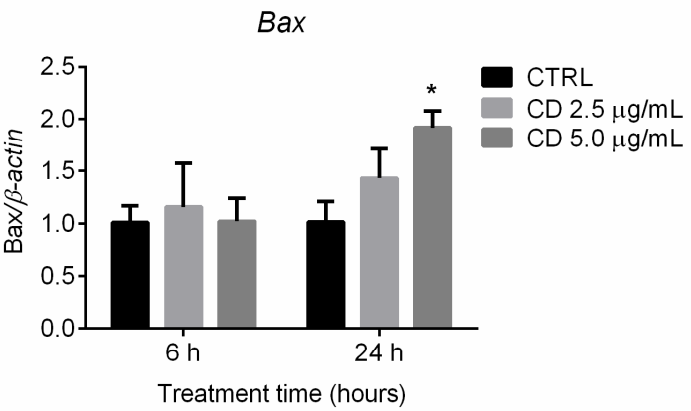

D

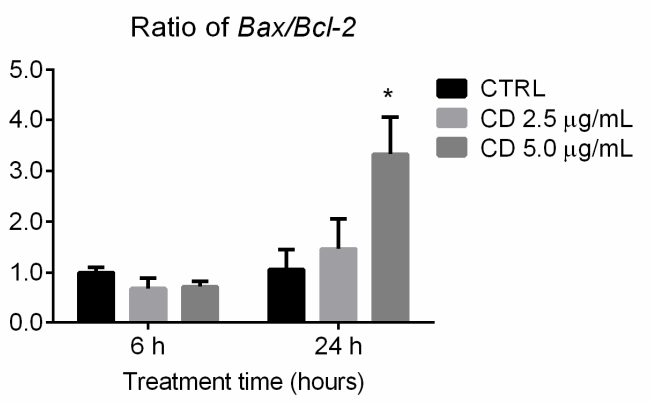

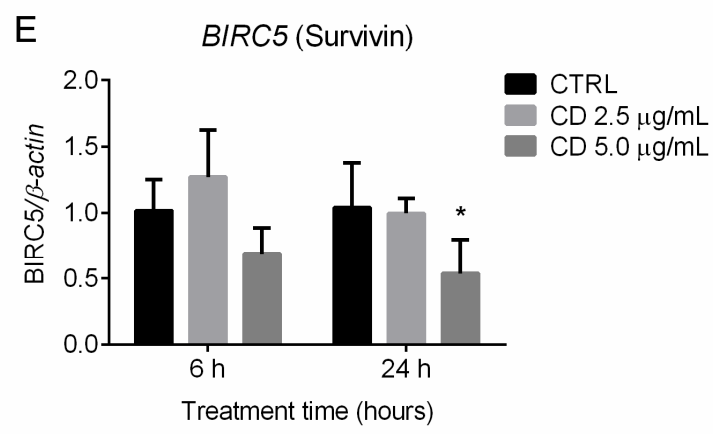

Figure 4: Effect of candidone on the expression of genes involved in proliferation and apoptosis. KKU-M156 cells were treated with candidone (CD) $(0,2.5$ or $5 \mu \mathrm{g} / \mathrm{mL})$ for 6 and $24 \mathrm{~h}$. The expressions of CDKN1A (p21), $B a x, B C l-2$, and BIRC5 (Survivin) were measured using RT-qPCR. Expression of target genes was normalized to the expression of $\beta$-actin. Data are expressed as mean \pm SD from three independent experiments; ${ }^{*} p<0.05,{ }^{* *} p$ $<0.001$ versus control group 


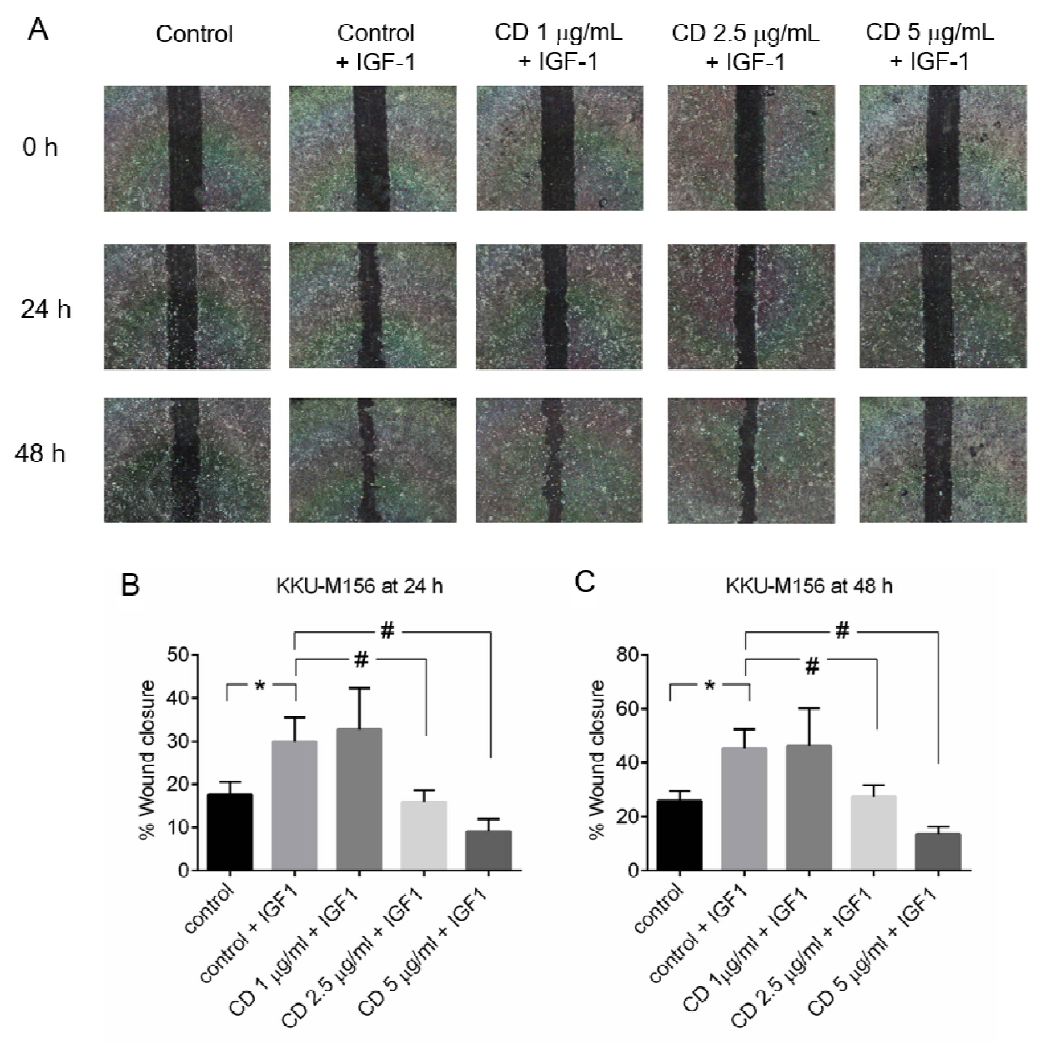

Figure 5: Candidone suppresses IGF-1 mediated CCA cells migration. The scratched wounds of KKU-M156 monolayer cells were treated with IGF-1 alone $(50 \mathrm{nM})$ or in the presence of candidone $(0,1,2.5 \mathrm{and} 5 \mu \mathrm{g} / \mathrm{mL})$ for $48 \mathrm{~h}$. Representative images from wound healing assay taken from the same field at 0,24 , and $48 \mathrm{~h}$ are shown (A). The percent of wound closure after 24 and $48 \mathrm{~h}$ is shown in $\mathrm{B}$ and $\mathrm{C}$. Data are expressed as mean \pm SD from three independent experiments; ${ }^{*} p<0.05$ compared to control group; $\# p<0.05$ compared to IGF-1 control group

Bax expression was unchanged at $6 \mathrm{~h}$, but significantly increased at $24 \mathrm{~h}$ (Figure $4 \mathrm{~B}$ ). In contrast, expression of the antiapoptotic gene $B C l-2$ decreased when treated with candidone for 24-h (Figure $4 \mathrm{C}$ ). However, the ratio of $\mathrm{Bax} / \mathrm{Bcl}-$ 2 was significantly increased in the $5 \mu \mathrm{g} / \mathrm{mL}$ candidone group (Figure $3 \mathrm{D}$ ). The antiapoptotic gene, BIRC5 (survivin) was also significantly suppressed by $5 \mu \mathrm{g} / \mathrm{mL}$ of candidone compared to untreated control in the $24 \mathrm{~h}$ treatment group (Figure $3 \mathrm{E}$ ). Taken together, these results suggest that candidone caused CCA cell death by modulating the expression of genes involved in proliferation and apoptosis.

\section{Candidone suppresses IGF-1 mediated CCA cells migration}

Wound healing assay was employed to examine the effects of candidone on inhibition of migration of CCA cells induced by IGF-1. IGF-1 significantly induced KKU-M156 cell migration compared to untreated cell. Treatment with candidone suppressed the migratory effect mediated by IGF-1 in a concentration-dependent manner (Figure $5 \mathrm{~A}$ ). Moreover, 2.5 and $5 \mu \mathrm{g} / \mathrm{mL}$ of candidone significantly suppressed wound closing after 24 (Figure $5 \mathrm{~B}$ ) and 48 hours (Figure $5 \mathrm{C}$ ). The results demonstrate that candidone significantly diminishes IGF-1 dependent CCA cell motility.

\section{DISCUSSION}

CCA is a biliary cancer with poor prognosis. Since there is no effective treatment for this fatal malignancy, many previous studies have investigated compounds to improve survival. Derris indica is widely grown in Thailand, an area in which CCA is endemic. The antitumor activity of candidone, a flavanone compound extracted from Derris indica, has been demonstrated in various cancers [10]. We therefore evaluated the antitumor effect of candidone in two CCA cells. The results illustrate that candidone has a cytotoxic effect against CCA cells, with IC50 values in the micromolar range. The compound mediates antiproliferation as well as apoptotic cell death in CCA cells. The effects of candidone are associated with alteration in the expression of genes involved in proliferation and apoptosis. 
Furthermore, candidone also inhibits cell migration.

Flavonoids have been documented as rich source of compounds with chemopreventive effects on cancer. Compounds in the flavanone class similar to candidone, such as hesperidin and naringin, show anticancer activity against breast and lung cancer [14, 15]. They mediate anticancer effects with selective toxicity towards cancer cells [16]. The antitumor effect of flavonoids including luteolin, quercetin, and EGCG in CCA are mediated through the suppression of JAK/STAT signaling $[9,17]$ and induction of mitochondrial cell death pathway [18]. In the present study, candidone showed a cytotoxic effect against two CCA cells, KKUM156 and KKU-M213, in the micromolar range. Notably, candidone mediates a rapid cytotoxic effect, which is evident as early as $8 \mathrm{~h}$ in both cell lines.

The effect of candidone on apoptotic cell death in CCA cells was elucidated by AO/EB fluorescence staining. Candidone at a concentration of 2.5 and $5.0 \mu \mathrm{g} / \mathrm{mL}$ induced apoptosis in KKU-M156 cells. It also suppressed cell proliferation, as shown by the decrease in percentage of live cells. Like other flavonoids, candidone mediates its antitumor effects through antiproliferation and induction of apoptosis.

We investigated the underlying mechanism of action of candidone by RT-qPCR. It was found that the expression of $C D K N 1 A$ (p21) mRNA was upregulated. p21 is a negative regulator of cell cycle progression, and its activation leads to suppression of cell proliferation. We then examined the expression of $\mathrm{Bax}, \mathrm{Bcl}-2$, and BIRC5 (survivin). Bax and Bcl-2 are known regulators of apoptosis through the intrinsic or mitochondrial cell death pathway. Bcl-2 and survivin play an important role as inhibitors of apoptosis. Bcl-2 is localized to the outer membrane of mitochondria and inhibits the proapoptotic proteins Bax and Bak from forming oligomeric mitochondrial pore, whereby cytochrome $\mathrm{C}$ is released from the mitochondrial matrix into cytosol and initiates apoptotic cell death cascade [19]. Survivin acts by inhibiting caspase activation and promoting cell survival [20]. The balance of $\mathrm{Bax}$ and $\mathrm{Bcl}-2$ regulates whether a cell will live or die [21], and the balance of Bax and Bcl-2 induced by candidone favors cell death.

Cancer progression is usually involved with invasion of surrounding tissues and metastasis into distant tissues. These processes are involved with migration capability of cancer cells.
Candidone induced suppression of cell migration at low cytotoxic concentration. In our wound healing assay, cell migration was stimulated by IGF-1. Candidone strongly inhibits cell migration in wound healing assay. This suggests that the anticancer activity of candidone involves the suppression of tumor invasion and metastasis.

\section{CONCLUSION}

The results of this study demonstrate that the phytochemical, candidone, mediates antitumor effect in CCA cells. This preclinical study provides new insights into the anticancer activity of flavanone derivatives from Derris indica. The precise underlying mechanisms by which candidone suppresses CCA should be further elucidated to develop a therapeutic compound in the treatment of cholangiocarcinoma.

\section{DECLARATIONS}

\section{Acknowledgement}

This work was supported by research grants from Khon Kaen University, Thailand (Grant No. 61003301) and grant from Faculty of Medicine, Khon Kaen University (Grant No. IN59231) and a scholarship from the Cholangiocarcinoma Research Institute (CARI) of Khon Kaen University to Benjawan Kurasug. The authors thank Dr. Justin Thomas Reese, for editing the MS via Publication Clinic KKU, Thailand.

\section{Conflict of interest}

No conflict of interest is associated with this work.

\section{Contribution of authors}

We declare that this work was done by the authors named in this article and all liabilities pertaining to claims relating to the content of this article will be borne by the authors. SK, VK, and AP designed the study, BK and SK performed experiments, CJ provided candidone compound, SK and VK wrote manuscript, SK analyzed the results and supervised the study. All authors approved the manuscript.

\section{REFERENCES}

1. Bridgewater J, Galle PR, Khan SA, Llovet JM, Park JW, Patel T, Pawlik TM, Gores GJ. Guidelines for the diagnosis and management of intrahepatic cholangiocarcinoma. J Hepatol 2014; 60(6): 1268-1289. 
2. Sripa B, Kaewkes S, Sithithaworn $P$, Mairiang E, Laha $T$, Smout M, Pairojkul C, Bhudhisawasdi V, Tesana S, Thinkamrop $B$, et al. Liver fluke induces cholangiocarcinoma. PLoS Med 2007; 4(7): e201.

3. Blechacz B, Gores GJ. Cholangiocarcinoma: advances in pathogenesis, diagnosis, and treatment. Hepatol 2008; 48(1): 308-321.

4. Valle JW, Wasan $H$, Johnson $P$, Jones $E$, Dixon $L$, Swindell R, Baka S, Maraveyas A, Corrie P, Falk $S$, et al. Gemcitabine alone or in combination with cisplatin in patients with advanced or metastatic cholangiocarcinomas or other biliary tract tumours: a multicentre randomised phase II study - The UK ABC-01 Study. Br J Cancer 2009; 101(4): 621-627.

5. Blechacz B, Gores GJ. Tumor-specific marker genes for intrahepatic cholangiocarcinoma: utility and mechanistic insight. J Hepatol 2008; 49(2): 160-162.

6. Baena Ruiz $R$, Salinas Hernandez $P$. Cancer chemoprevention by dietary phytochemicals: Epidemiological evidence. Maturitas 2016; 94: 13-19.

7. Chikara S, Nagaprashantha $L D$, Singhal J, Horne $D$, Awasthi S, Singhal SS. Oxidative stress and dietary phytochemicals: Role in cancer chemoprevention and treatment. Cancer Lett 2018; 413: 122-134.

8. Meng S, Zhu Y, Li JF, Wang X, Liang Z, Li SQ, Xu X, Chen $H$, Liu $B$, Zheng $X Y$, et al. Apigenin inhibits renal cell carcinoma cell proliferation. Oncotarget 2017; 8(12): 19834-19842.

9. Aneknan $P$, Kukongviriyapan $V$, Prawan A, Kongpetch $S$, Sripa $B$, Senggunprai L. Luteolin arrests cell cycling, induces apoptosis and inhibits the JAK/STAT3 pathway in human cholangiocarcinoma cells. Asian Pac J Cancer Prev 2014; 15(12): 5071-5076.

10. Al Muqarrabun LM, Ahmat N, Ruzaina SA, Ismail NH, Sahidin I. Medicinal uses, phytochemistry and pharmacology of Pongamia pinnata (L.) Pierre: a review. J Ethnopharmacol 2013; 150(2): 395-420.

11. Decharchoochart $P$, Suthiwong J, Samatiwat $P$, Kukongviriyapan V, Yenjai C. Cytotoxicity of compounds from the fruits of Derris indica against cholangiocarcinoma and HepG2 cell lines. J Nat Med 2014; 68(4): 730-736.
12. Buranrat $B$, Senggunprai L, Prawan $A$, Kukongviriyapan $V$. Simvastatin and atorvastatin as inhibitors of proliferation and inducers of apoptosis in human cholangiocarcinoma cells. Life Sci 2016; 153: 41-49.

13. Suphim B, Prawan A, Kukongviriyapan U, Kongpetch $S$, Buranrat $B$, Kukongviriyapan $V$. Redox modulation and human bile duct cancer inhibition by curcumin. Food Chem Toxicol 2010; 48(8-9): 2265-2272.

14. Febriansah R, Putri DD, Sarmoko, Nurulita NA, Meiyanto $E$, Nugroho $A E$. Hesperidin as a preventive resistance agent in MCF-7 breast cancer cells line resistance to doxorubicin. Asian Pac J Trop Biomed 2014; 4(3): 228233.

15. Hsiao YC, Kuo WH, Chen PN, Chang HR, Lin TH, Yang WE, Hsieh YS, Chu SC. Flavanone and 2'-OH flavanone inhibit metastasis of lung cancer cells via downregulation of proteinases activities and MAPK pathway. Chem Biol Interact 2007; 167(3): 193-206.

16. Hwang KA, Choi KC. Anticarcinogenic Effects of Dietary Phytoestrogens and Their Chemopreventive Mechanisms. Nutr Cancer 2015; 67(5): 796-803.

17. Senggunprai L, Kukongviriyapan V, Prawan A, Kukongviriyapan U. Quercetin and EGCG exhibit chemopreventive effects in cholangiocarcinoma cells via suppression of JAK/STAT signaling pathway. Phytother Res 2014; 28(6): 841-848.

18. Kittiratphatthana $N$, Kukongviriyapan $V$, Prawan $A$, Senggunprai $L$. Luteolin induces cholangiocarcinoma cell apoptosis through the mitochondrial-dependent pathway mediated by reactive oxygen species. J Pharm Pharmacol 2016; 68(9): 1184-1192.

19. Hata AN, Engelman JA, Faber AC. The BCL2 Family: Key Mediators of the Apoptotic Response to Targeted Anticancer Therapeutics. Cancer Discov 2015; 5(5): 475-487.

20. Altieri DC. Validating survivin as a cancer therapeutic target. Nat Rev Cancer 2003; 3(1): 46-54.

21. Paul-Samojedny $M$, Kokocinska D, Samojedny A, Mazurek U, Partyka R, Lorenz Z, Wilczok T. Expression of cell survival/death genes: $\mathrm{BCl}-2$ and $\mathrm{Bax}$ at the rate of colon cancer prognosis. Biochim Biophys Acta 2005; 1741(1-2): 25-29. 